\title{
Toward a Historically Accountable Critical Whiteness Curriculum for Social Work
}

\author{
Joshua R. Gregory
}

\begin{abstract}
Whiteness-distinct from individuals who identify as white-is a social construction; and social constructions, by definition, can be disassembled. Whiteness is also wholly constituted by and inseparable from white supremacy, and thus exists purely as racial injustice. These are historical facts. Consequently, racial justice demands that whiteness be dismantled and abolished. Social work, as a profession committed to racial justice, is directly implicated in this imperative. Yet, due to misunderstanding and unawareness, the above facts register with most social workers as exaggerated claims, baseless untruths, or ideological propaganda. Social work requires a historically accountable critical whiteness curriculum in order to correct this pervasive misunderstanding and to facilitate informed participation in the pursuit of racial justice in a way that accurately apprehends the nature of whiteness. This curriculum, introduced here, explores the history and invention of whiteness in global, U.S., and social work contexts; examines the integral role of education in deploying and maintaining whiteness; and considers reconstruction and abolition as alternative modes of responding to whiteness as a social problem. The curriculum ultimately shows abolition to be the only historically and theoretically consistent response to whiteness, leading to a call for abolition as praxis and for further curricular development.
\end{abstract}

Keywords: Whiteness, social work, history, curriculum, pedagogy

This project originates from and speaks directly to one simple fact: whiteness is a social problem. White privilege (McIntosh, 1989) is not a social problem; white fragility (DiAngelo, 2018) is not a social problem; white silence (Smalling, 2015) is not a social problem; but, more accurately, each is a symptom of one underlying social problemnamely, whiteness. This is not to deny that white privilege, fragility, and silence are pervasively and severely harmful, but to point out that to eradicate any or all of these will still leave intact whiteness as the root cause from which they stem. Whiteness left intacteven absent privilege, fragility, or silence-will perpetuate racial oppression (Nopper, 2010). That is because whiteness is, by definition, wholly constituted by and inseparable from white supremacy (Ignatiev, 1997; Ignatiev \& Garvey, 1996). Or, as David R. Roediger (1994) put it, "It is not merely that whiteness is oppressive and false; it is that whiteness is nothing but oppressive and false" (p. 13). Whiteness is, therefore, not just a social problem, but a categorical social problem.

Social work's orientation toward whiteness as a categorical social problem should be easily predictable and unwavering, but it is not ${ }^{\mathrm{i}}$. Other unambiguously harmful social problems make their way quickly onto social work agendas as injustices to which the profession stands unequivocally opposed and that legions of social workers rally fervently to combat. The normative course of action in such cases is never hesitant or partial, but imperative and absolute - total elimination, or, to use the popular language of rising social

Joshua R. Gregory, A.M., doctoral student, School of Social Welfare and Program in Critical Theory, University of California, Berkeley CA.

Copyright (C) 2021 Authors, Vol. 21 No. $2 / 3$ (Summer 2021), 616-634, DOI: 10.18060/24094

(cc) BY

This work is licensed under a Creative Commons Attribution 4.0 International License. 
work generations, abolition. Social work has historically aimed to completely end categorical social problems like hunger, crime, violence and poverty (the notions of aspiring to alleviate most hunger or to prevent some violence would undoubtedly register with most social workers as falling short of their professional mandates and as abandonment of moral responsibility). Further, growing numbers of prominent social work scholars, activists, and practitioners are pronouncing the need to abolish prisons (e.g., Chandler, 2018; Richie \& Martensen, 2020), and have recently taken to even more controversial abolition projects targeting the police (Abrams \& Dettlaff, 2020) and the child welfare system (Dettlaff et al., 2020), all of which are arguably more difficult to classify as categorical social problems than hunger, crime, violence, poverty, or whiteness. A burgeoning national social work collective and infrastructure has even recently progressed to the point of formal institutionalization as the Network to Advance Abolitionist Social Work (NAASW), focusing foremost on carcerality, but also promoting abolitionist social work praxis more broadly (see Network to Advance Abolitionist Social Work, 2021). The historically consistent, socially just, and increasingly accepted position is thus for social work to commit, as it has in relation to other categorical social problems, to the abolition of whiteness.

But social work has not embraced or even seriously entertained the abolition of whiteness, instead preoccupying itself with treating the aforementioned symptoms of whiteness rather than rooting out their cause (e.g., Jeyasingham, 2012; Lee \& Bhuyan, 2013; Nylund, 2006), in effect thereby endorsing only half-measure solutions to the most insidious and impactful categorical social problem facing the United States today (see also de Montigny, 2013; Dominelli, 1989). Setting aside for the time being whatever the reason might be that social work has so far proven either unwilling or unable to recognize the abolition of whiteness as crucial to racial justice, the mere fact that it has not yet come to this realization necessitates a historically accountable critical whiteness curriculum for social work. This curriculum, which will be introduced momentarily, meets social work where it is at (i.e., unaware that whiteness must be abolished or why) and gets it where it needs to go (i.e., committed to the abolition of whiteness). ${ }^{\text {ii }}$ Accordingly, this curriculum does not accommodate apologies for whiteness that attempt to reconstitute or misrepresent any part of whiteness as worth saving; which is to say that it sticks to historical-material fact. Many will cast this pedagogical approach as ideological, when, in reality, it is that very objection which is ideological, given that it is only possible to see whiteness as anything other than oppressive and false through disconnection from historical-material fact. And this distinction is precisely the lesson the curriculum strives to impart to social work in pursuit of racial justice.

\section{Mapping the Critical Whiteness Curriculum}

This project uses an article format to introduce a historically accountable critical whiteness curriculum for social work. It is instructive, for what follows, to begin by unpacking the implications of that statement. First, this is an article about a curriculum. As such, it is neither fully an article nor entirely a curriculum, but a scaffold fusing elements of each in order to facilitate engagement that moves always from thinking in terms of the former toward elaborating the larger project of the latter. To that end, each section should 
be read as both describing to an external observer (i.e., reader) the topic and method of a given unit in the curriculum and exposing an internal participant (i.e., student) to the initial pedagogical encounter with that topic and method.

Second, it is the task of this project, vis-à-vis the curriculum, to introduce-introduce in the sense of positing a preliminary plan that is intended not as fixed or yet exhaustive, but which asserts what is estimated to be the best possible intervention at the present time with the knowledge available. The curriculum, as developed here, should endure as a moreor-less stable topical and methodological core to be amended, revised, and refined in response to the inevitable changes in and around whiteness, social work, and the ways in which they interact and intersect.

Third, the curriculum is historically accountable. This situates historical accountability, or accountability to history, as a necessary condition of any critical whiteness curriculum. In other words, without rigorous attention to the historical context that produces and is produced by whiteness, the curriculum cannot possibly meet its obligation to grapple with whiteness according to its etiology in lived experience. Lack of historical accountability is exactly what leads to popular (Bonilla-Silva, 2003), academic (Leonardo, 2009; Matias, 2016), and legal-institutional (López, 2006) definitions of whiteness that are based more on myth and (often deliberate) misinterpretation than evidence and actuality. The resulting modes of ahistorical understanding fail to grasp whiteness for what it is (and is not). Indeed, few social workers - or people in general, for that matter - can offer a historically informed definition of whiteness.

Fourth, this project sets upon building a critical whiteness curriculum. Each unit of the curriculum, though unique in many ways, shares the common objective of contributing to a multifaceted, cohesive critique of whiteness as a historical-material fact, social construction, and lived reality. This description should not be taken to signify any affiliation with the formally institutionalized academic discipline of Critical Whiteness Studies (see Hartman, 2004; Kincheloe \& Steinberg, 1998; Niemonen, 2010; Twine \& Gallagher, 2008), which, by aspiring to reconstruct rather than abolish whiteness, implicitly takes critique to be more of an end in itself than a means.

Lastly, the curriculum is for social work; it is not of, by, or in social work, in the sense that these alternative prepositions would suggest a self-produced social work curriculum or a curriculum assembled using tools and materials within social work. The curriculum addresses and caters to but originates outside of social work, drawing from topics and methods that social work does not traditionally engage in but which stand to immensely benefit social work's overarching mission of social justice. The curriculum is also for social work in the sense that it is presented with the full intention that social work take possession of it, adapt it, and use it such that it may generate - and itself be regenerated by-novel forms of liberatory social work praxis.

This historically accountable critical whiteness curriculum is delineated below in three sections which are designated as units of the curriculum, and that contain subsections corresponding to unit-specific lessons. Unit one introduces the method of dialectical materialism and its application in capturing histories of whiteness based in global development, the U.S. nation state, and social work. Unit two places the process of 
education in reflective context to preemptively elucidate ways that whiteness might affect (or infect) the very modes of pedagogy upon which this and other curricula are forced to depend. Unit three arrives at the present state of whiteness and considers theoretical and practical paradigms for responding to whiteness, ultimately demonstrating abolition to be the only treatment of whiteness that is supported by the information revealed over the course of the preceding curriculum, and that aligns, in practice, with social work's ostensible devotion to racial justice.

Figure 1. A Historically Accountable Critical Whiteness Curriculum for Social Work

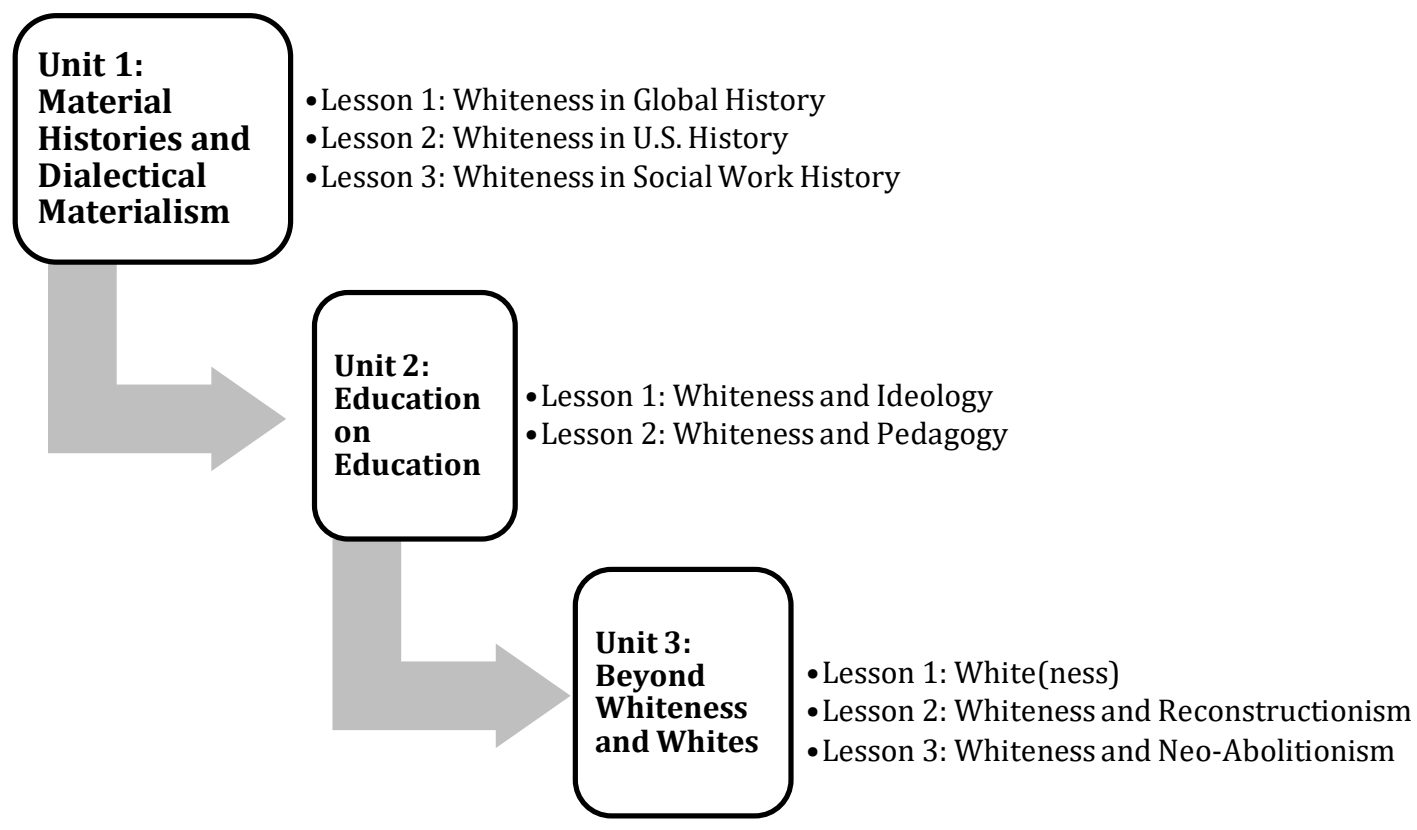

\section{Unit One: Material Histories and Dialectical Materialism}

In unit one, the essential content in which facilitators must possess proficiency and that students must internalize consists in understanding that whiteness has not always existed, that whiteness was and is (re)invented, maintained, and deployed by and in discrete individual, collective, and institutional actions prior to becoming a ubiquitous social construction; and that these processes penetrate global history, U.S. history, and social work history (see Baldwin 1985; Du Bois, 1903/2014, 1935; Morrison, 1970). This understanding is accessible through the analytical framework of dialectical materialism, which is most often attributed to Marx (see Marx \& Engels, 1932/1970), but is an extension of earlier philosophies that focused more exclusively on the material determinants of historical progress (e.g., Feuerbach, 1893; Ricoeur, 1986). What dialectical materialism contends, in short simplification, is what has just been stated regarding whiteness: social constructions (e.g., whiteness) first result from material conditions (e.g., colonialism and 
capitalism), after which point the social and the material reciprocally influence and, indeed, form each other. This formative reciprocation is what is implied by the word "dialectical" in the name; that is, the social is formed in part by the material, and material is, in turn, formed in part by the social, each coming eventually to exist as a pure form of neither, but a mixture of both, and each with its respective namesake taking up the greater share of the form. The word "materialism" in the name indicates, however, that it is the material, not the social, which initiates and dominates this relationship - material change is more likely to force social change than vice versa. In unit one, dialectical materialism is just as important to facilitators and students as the contents concerning global, U.S., and social work history, each of which takes a turn as the critical object of this analytical framework.

Whiteness and global history. The first lesson topic in unit one is that whiteness did not used to exist - anywhere in the world (Allen, 1994-1997; Kendi, 2016). This does not mean that there were no human beings who might today be classified as white, but that the material fact of a pale phenotype was invested with no social significance. The prospect of white supremacy would have made about as much sense then as it would make today to predict that all of humankind will be organized into a hierarchical global society in which those with thick knuckle hair are presumed superior to their comparatively smooth-skinned counterparts and privileged accordingly. ${ }^{\mathrm{iii}}$

Obviously, things have changed since then. Dialectical materialism, by assuming some material antecedent for every social construction, compels a historical search for whatever impetus in materiality may have contributed to the global paradigm shift that gradually rendered whiteness (read: white supremacy) a thoroughly normalized fact of life. This search comprises the substance and process of the first lesson in unit one. Here, the facilitator guides the student on an exploratory journey to excavate changes in historicalmaterial circumstance by which light color (and, by extension, light skin) was arbitrarily imbued with social desirability, and thus implicitly juxtaposed with dark color (and, by extension, dark skin) as socially undesirable (Dyer, 1997; Painter, 2010). These instances represent the seeds of nascent whiteness as a necessary developmental stage, for whiteness did not suddenly burst forth into the world in its recognized and dominating form. These incremental precursors represent inflection points that would eventually support and explain the full-fledged emergence of whiteness as an inherently oppressive, institutionally sanctioned, enveloping social relation, as it exists today.

To note just one example, Ibram X. Kendi (2016) offers a generative starting point for this search in Part I of his award-winning book, Stamped From the Beginning. The African slave-trade initiated by Prince Henry of Portugal in 1415 eventually came to serve as a glorified model and historical touchstone for the future evolution of race and whiteness. Interestingly, Prince Henry's desire for material conquest was unmotivated by any conception of race or racism. It was, however, retrospectively rationalized and romanticized in terms of color (see de Zurara, 1963; Russell, 2000), laying the contrived intellectual foundation upon which subsequent slave-trading campaigns would build in order to justify the enslavement of persons with darker skin. Kendi (2016) himself, ascertains the very point dialectical materialism hopes to capture in this first lesson of unit one, emphasizing that "inaugural racist ideas, in other words, were a product of, not a producer of, Prince Henry's racist policies concerning African slave-trading” (p. 23). 
Whiteness and U.S. history. The second lesson topic in unit one is that the AngloAmerican colonies invented whiteness. Given that the previous lesson reviews historicalmaterial events leading to but still predating the advent of whiteness, and considering the sadly common knowledge that the United States was founded upon a slave economy that subsisted on white supremacy and Black dehumanization, it is logical to deduce that, by the seventeenth century, the pivotal historical-material turning point is imminent and likely an American domestic product. Theodore W. Allen (1994-1997) notes the following: "When the first Africans arrived in Virginia in 1619, there were no 'white' people there. Nor, according to colonial records, would there be for another sixty years" (p. x). Whiteness would soon become the single most consequential American invention and export in all of history, permanently altering the course of U.S. and global society.

Though the fact remains that, as already stated, whiteness did not simply appear instantaneously as a relational social identity, the dialectical materialist approach allows for the most precise approximation possible of the historical moment, broadly speaking, when certain people responded to material change in their environment by identifying for the first time as white. That historical moment was Bacon's Rebellion in Virginia, 1676. The rebellion created such destabilizing unrest that the small European landed aristocracy moved to devise a means by which to divide the two much larger populations of landless European peasants and enslaved Africans from each other, preventing them from persisting in cooperative rebellion against class oppression (Allen, 1994-1997; Kendi, 2016). "The answer to the problem, obvious if unspoken and only gradually recognized, was racism, to separate dangerous free whites from dangerous slave blacks by a screen of racial contempt" (Morgan, 1975, p. 328). And so in response to a threat to material class interest, the early Anglo-American colonists invented whiteness, a social construct that they gradually reinforced with legal and institutional protections (Hening 1823; Neill, 1875; Thandeka, 2000 ) in order to secure power and privilege at the direct expense of Blackness (see also Anderson, 2016, on whiteness and U.S. history).

Whiteness and social work history. The third lesson topic in unit one is that whiteness and social work have evolved in ways that have mutually affected each other; whiteness has informed what it means to be a social worker and to practice social work, while social work has influenced what it means to be identified and to identify as white (Gregory, 2020a). As with the first lesson in this unit, which focused on white global history, this lesson, too, can be approached in an exploratory manner. Reciprocity between whiteness and social work manifests in cases far too numerous to catalogue exhaustively (see Dominelli, 1989; Fox, 2012; Goldberg, 2008; Gustafson, 2009; Katz, 1986; Pimpare, 2007; Piven \& Cloward, 1993), so various selections from the possible instances that serve as adequate examples can effectively demonstrate this symbiosis however the facilitator might like to contextualize the lesson in relation to geography, politics, culture, religion, etc. One recommended topic for making inroads to the substance of this lesson is the relationship between early social welfare and the first U.S. social sciences (e.g., anthropology). Social welfare's eager appropriation of social scientific methods-which relegated BIPOC (Black, Indigenous, and people of color) to subhuman biological and social strata (Gould, 1996) - summarily excluded BIPOC from the socially constructed 
boundaries of "deservingness" that determined the selective distribution of aid (Leiby, 1978).

Notwithstanding the gravity of every similar such occasion when social welfare - and eventually the formalized profession of social work - marginalized and mistreated BIPOC by its very nature as a product and project of whiteness, the more serious implication of social welfare's historical relationship with whiteness comes to bear upon the way that mainstream social work identifies itself as a profession today. Stated plainly, through complicity in whiteness, social work systemically misunderstands and misrepresents itself at the individual, collective, and institutional levels as external and opposed to, rather than integral to, the historical development of racism and racial injustice. This is the overarching conclusion of lesson three, which synthesizes the essential takeaways from the previous lessons on whiteness in global and U.S. history and situates them in direct relation to social work.

\section{Unit Two: Education on Education}

In unit two, the essential content in which facilitators must possess proficiency and that students must internalize consists in understanding that the education system is enmeshed with whiteness and operates to (re)produce students as subjects who are legible according to the terms of whiteness. For the benefit of both the reader and the future student of this curriculum, it is and will be important to contextualize this unit in two ways. There is a chance that the topic of this unit (i.e., whiteness vis-à-vis education) might be perceived as peripheral or superfluous in comparison to the more direct connections to whiteness apparent in the other two units; and there is some risk that the lessons in this unit might be read in a way that is overdetermined, meaning more generalized and definitive in theory than turns out to be the case in practice. Regarding the former concern, simply note the centrality of the education system as a mediator of any socioculturally transmitted influence (e.g., whiteness) on young persons, given the national out-of-school rate of roughly one percent (UNESCO Institute for Statistics, 2020) and the homeschooling rate of approximately three percent (National Center for Education Statistics, 2018). Note also the fact that professional social work depends on the education system for its very existence. As for the latter apprehension, it is a fair criticism that the theories discussed in this unit were originally presented by their authors as perhaps more explanatory than they really are. The theories should be taken as informative in every context, determinative in no context. This is important to clarify in order to leave room for the possibility of change that is necessary if there is to be hope for liberation from the oppression that is innate to contemporary life under the reign of whiteness.

Whiteness and ideology. The first lesson topic in unit two derives from French Marxist philosopher Louis Althusser's (1971) theory of ideological state apparatuses (ISAs) and interpellation. But before going any further, this necessitates an all-too-brief aside on the all-too-loosely applied concept of ideology. As developed most famously by Marx, ideology is best understood in opposition to what one might colloquially refer to as that which is real or true (Marx \& Engels, 1932/1970; see also Ricoeur, 1986). Thinking or acting ideologically, therefore, is for one to be guided not by that which is real or true 
(again, in the informal sense), but by one's idea of that which is real or true, which, of course, is subject to any and all sorts of subjective deviations. And it is a characteristic of ideology to substitute itself $a$ s that which is real or true rather than a subjective relation to it. This should sound readily familiar to U.S. social workers living amid the political climate of the year 2020, who likely encounter quite regularly the experience of a struggle to reach consensus with differently-minded others, not over opinions related to facts, but over facts themselves. This slippage in agreed-upon reality and truth depending upon subjective position is ideology at work.

Continuing now to Althusser (1971), ISAs are those institutions (e.g., the school, the church, the family, etc.) that the state depends upon to disseminate its dominant ideology, but which are not always identified entirely with that function (i.e., the family is clearly more than just a state propaganda machine). Althusser proposes that, in capitalist society, the school has surpassed the church as the primary ISA. Interpellation, he further asserts, is the process of recognition by which the dominant ideology constitutes individuals as "always-already subjects" (p. 176). Though quite complex and impossible to elaborate in full within the constraints of introducing the curriculum at hand, this ideological corollary of interpellation essentially theorizes that by the mere fact of living in social contact with society as it is organized by the state, it is always the case that one can only be recognized by others and recognize oneself in terms already compatible with the dominant ideology. ${ }^{\text {iv }}$ This abstract description will become clearer in the following summarizing example.

The lesson is that, in the U.S. nation state, the ISAs - the school, first and foremostfacilitate the dominance of an ideology that is inextricably conditioned by whiteness (though it is, of course, also bound up with other determinants such as capitalism, nationalism, and heteronormativity). This ideology interpellates individuals as subjects assimilable to whiteness, meaning that individuals always recognize themselves and are recognized by others in terms of whiteness. Since, again, whiteness is coextensive with white supremacy, these terms imply that recognition as white entails recognition as not $\mathrm{BIPOC}$, and recognition as BIPOC entails recognition as not white, the former having the effect of ideological supremacy, the latter of ideological oppression. And these ideological relations exert material consequences.

Whiteness and pedagogy. The second lesson topic in unit two follows from French sociologist Pierre Bourdieu's theories on pedagogy and cultural reproduction (Bourdieu, 1991; Bourdieu \& Passeron, 1990). If the dominant U.S. ideology is produced by and produces whiteness, and if this process depends largely upon schools and interpellation therein, there is still room to specify the mechanics of how students are continuously constituted and reconstituted as always-already subjects indissolubly related to whiteness. So far, the question of "how" has not been answered beyond it being located somewhere in the immersion of the student in the school environment. Bourdieu goes further, explicating the roles of pedagogy and language in schools as means of reproducing subjects of the dominant ideology. Here again, it is impossible, in an introduction to this curriculum, to do justice to the full scope and depth of the theoretical content. That task is reserved for curriculum implementation, sketching only an outline for now. In distilled form, Bourdieu claims the following regarding pedagogy and language: the ideologically presumed, authoritative pedagogue (i.e., teacher) inculcates the student with understanding that 
comports with the dominant ideology; this understanding cultivates in the student a subjectivity that is dialectically related to the dominant ideology —neither purely individual nor ideological, but necessarily a synthesis of both, which Bourdieu calls habitus; the habitus guides the student's material practice in such a way as to guarantee the reproduction of the objective structures that, in the first place, secured the culture of the dominant ideology by which, among other things, the aforementioned pedagogue was presumed to be an authority. And this cultural, pedagogical reproduction of the dominant ideology and its subjects transpires in the medium of language - a sign system with the capacity to inflict what Bourdieu calls the symbolic violence of assimilating an individual to the dominant ideology, even interpellating an individual as a subject of that dominant ideology, in direct contradiction with their best interest and autonomy (see also Vološinov, 1986).

The lesson, as it relates to whiteness, carries forward from the preceding lesson on ISAs and interpellation, but increases in specificity. Beyond the "what" (i.e., schools traffic in the dominant ideology and constitute subjects accordingly), the "how" is now evidentstudents acquire the dominant ideology through pedagogy and as a product of language. And given the already established coincidence of whiteness with the dominant U.S. ideology, it follows that students in the United States are recruited as participants in whiteness through the content of the schooling they receive and the language of their lessons. This conclusion aligns with the growing body of evidence of the myriad ways that whiteness thoroughly pervades education (e.g., Allen, 2004; Applebaum, 2017; BonillaSilva \& Zuberi, 2008; Leonardo \& Manning, 2017). Students are inscribed with the ideological imprimatur of whiteness not by diffuse absorption of something nebulous in the ether of the school environment, but by direct transfer of the very instructional substance that is part and parcel of the U.S. education system.

\section{Unit Three: Beyond Whiteness and Whites}

In unit three, the essential content in which facilitators must possess proficiency and that students must internalize consists in understanding that the conflation of whiteness and whites has forestalled effective social and political action against whiteness; reconstructionism addresses symptoms but not causes of racial injustice vis-à-vis whiteness, thereby reifying whiteness through incorrectly framing the problem; and neoabolitionism represents the only response to whiteness that is historically consistent and practically aligned with the goal of racial justice. After two units spent solidifying the prerequisite familiarity with the history of whiteness and the primary means by which it is reinforced and spread, unit three finally turns toward the collective activity of responding to whiteness. This transition is imperative if the curriculum is to assist social work in moving beyond theory to a mode of praxis that directly addresses whiteness as a categorical social problem.

White(ness). The first lesson topic in unit three is the rampant confusion regarding the conceptual boundary between whiteness and whites, along with the ways that this misinterpretation impedes and distracts social progress. The greatest accomplishment of whiteness has been to convince the world that whites, as such, exist. ${ }^{\mathrm{v}}$ Today, any conceptual separation between whiteness and whites strikes most as mind-bendingly 
difficult to fathom. Even though biologically determined theories of race as an immutable trait have steadily declined over the better part of the last century (Obasogie et al., 2015), few people have entertained the further prospect of letting go of whiteness as it is socially constructed. As many gain clarity around the fact of whiteness and white supremacy as the selfsame phenomenon, they paradoxically lament what they perceive to be the insurmountable challenge of whiteness as an ineradicable social construction, although it is precisely that which has been socially constructed that can be deconstructed and disposed. In spite of the unwilling reactionaries (e.g., Gilbert, 2016) or the unwitting conformists (see Hartmann et al., 2009), even those who critically engage the social problem of whiteness all too often orient themselves to intervention in ways that make an oxymoron out of whiteness as an allegedly irreversible social construction. This is because prevailing understanding conflates whiteness with whites.

Whiteness is a social construction; whites are individuals who positively identify or are affirmatively recognized in relation to whiteness. Whether whiteness flourishes, decays, or disappears altogether, the individual does not change; but the relation of the individual to whiteness may change. It is only because the social construction of whiteness has, since its invention, subsumed nothing other than countless desires for the acquisition of capital ${ }^{\mathrm{vi}}$ in various forms (e.g., social, cultural, economic, political) that it is systemically mistaken for something incorporated by and in the individual; it is something the individual has and is (see also Harris, 1993; Lipsitz, 1998). This erroneous attribution of whiteness as rather than to individuals has the effect of inhibiting social or political resistance to whiteness, given the much more precarious task for activists of combating people than an idea, as well as the more impassioned resistance elicited in defense of the self than a relation. Put differently, the conflation of whiteness with whites is what leads people to take anti-racism as a personal affront; it is what compels Donald Trump and those in service to him, in the year 2020, to issue an executive memorandum condemning the concept of white privilege and the analytical paradigm of critical race theory as "divisive, false, and demeaning propaganda" (para. 5) and as "anti-American" (Vought, 2020, para. 1), as if individuals, rather than social constructions, were under scrutiny.

Whiteness and reconstructionism. The second lesson topic in unit three is the reconstructionist response to whiteness. Reconstructionism describes probably 95 percent of research, scholarship, and sociopolitical practice that responds directly to whiteness (see Kincheloe et al., 1998, for the programmatic reconstructionist text; see also Leonardo, 2009 , pp. $61-74$, on reconstructionism). ${ }^{\mathrm{vii}}$ It is a general, descriptive category, not a selfdesignation among those to whom it applies. The name is relatively transparent about what this mode of response to whiteness entails (i.e., the reconstruction of whiteness), but it is important to explicitly draw out the two implicit, definitive parameters that set the reconstructionist agenda.

First, reconstructionism insists that whiteness change in a way that is decidedly antiracist. Second, reconstructionism assumes the persistence of whiteness in some form, thus problematizing symptoms of whiteness, not its existence. Reconstructionists diverge methodologically in both subtle and significant ways, but they are unified in the fact that they provide no justification for this second tenet, making it an assumption in the absolute sense. Instead, when the subject is broached of a world without whiteness, 
reconstructionists characteristically make an argument about whites rather than whiteness. ${ }^{\text {viii }}$ Shannon Sullivan (2014) is exemplary in this regard when she directly addresses the social movement for the abolition of whiteness, writing, "I object to its mission because it underestimates the significance of whiteness to many people's identities and habits, and not just those who are avowed white supremacists" (p. 141). Confronted by the abolition of whiteness as a hypothetical, Sullivan says nothing about whether whiteness can be abolished, but weighs in on whether it should be abolished, claiming that, in fact, it should not, citing the "significance" of whiteness to whites. The signature of reconstructionism is any argument similar to Sullivan's, which answers questions about possibility with concerns about plausibility. Every time, in whatever form, this amounts to an assertion that whiteness cannot be abolished because it would be too hard.

Whiteness and neo-abolitionism. The third lesson topic in unit three is the neoabolitionist response to whiteness. If the above estimate is accurate, then it follows that neo-abolitionism encompasses somewhere around five percent of the research, scholarship, and sociopolitical practice that responds directly to whiteness. The late Harvard professor Noel Ignatiev and his collaborator John Garvey founded the still-marginal neo-abolitionist movement in the late 1990s, publishing the sole explicitly neo-abolitionist text, Race Traitor, in 1996. The movement was also intellectually sustained by significant empirical and theoretical contributions from Roediger $(1991,1994)$. These scholars are mentioned in text rather than parenthetically because, contrary to reconstructionism, neo-abolitionism is a program with which individuals do self-identify (though Roediger has maintained a safe distance in practice despite his written pronouncements). And these three, collectively, set the terms of neo-abolitionism in their own words. Ignatiev and Garvey (1996) situate neoabolitionism as a theoretical possibility, contending "first, that the 'white race' is not a natural but a historical category; second, that what was historically constructed can be undone" (p. 35). Roediger (1994) attempts to motivate the abolition of whiteness as a sociopolitical intervention, opining:

We cannot afford to ignore the political implications of the mass questioning of whiteness as a trend and a possibility in the US. In a variety of settings . . . whites are confessing their confusion about whether it is really worth the effort to be white. We need to say that it is not worth it and that many of us do not want to do it. (p. 16)

As Ignatiev and Garvey point out, neo-abolitionism is theoretically consistent with historical-material fact (which students will, by this point, realize based upon the first two units of the curriculum). It targets the abolition of whiteness as the unavoidable first step toward deconstructing the overarching social typology of race, which sustains racial inequity and injustice. Zeus Leonardo (2009) sums up the rationale for taking on whiteness directly as a necessary and efficacious strategy for dealing with the larger problem of race when he states that "without a privileged center, there can be no denigrated margin" ( $p$. 71). But neo-abolitionism has never developed a means of praxis - theory-informed practice and practice-informed theory. In fact, neo-abolitionism has hardly begun to articulate any plan even for mere practice, save anecdotal evidence of white individuals giving their best ad hoc, subjective, inconsistent interpretations of what it might look like to embody and enact a new, chosen identity that they describe as a "race traitor" (see 
Ignatiev \& Garvey, 1996). While reconstructionism lacks a coherent theoretical foundation but proceeds nonetheless to practice, neo-abolitionism, conversely, begins from a theoretically sound point of departure without any plan for practical implementation. In their present forms, neither can offer a viable path to racial justice. But neo-abolitionism at least contains the potential to eventually, in a more mature form, break through the limitations of a human condition that is existentially constricted by whiteness and the social construction of race.

\section{Conclusion: Notes Toward Implementation}

The historically accountable critical whiteness curriculum for social work that is proposed here attempts to cover a lot of ground: global origins of color distinctions leading to colorism; the invention of whiteness and attendant racism; the formation of social work alongside of whiteness; state deployment of white ideology and the creation of subjects in relation to whiteness; schools and the uses of pedagogy and language in the cultural reproduction of white ideology and subjects in relation to whiteness; the relationship between whiteness and whites; the reconstruction of whiteness (reconstructionism); and the abolition of whiteness (neo-abolitionism). To teach these topics comprehensively over the course of a curriculum presents an immense challenge; to introduce these topics completely here is impossible. Again, each section should be read as both describing to an external observer (i.e., reader) the topic and method of a given unit in the curriculum and exposing an internal participant (i.e., student) to the initial pedagogical encounter with that topic and method. What is written here should be taken as the beginning, not the entirety, of the curriculum content, along with clear indications of where to expand and suggestions for resources and strategies that will aid in fully bringing the curriculum to fruition. Table 1 provides discussion questions designed to both deepen learning and to facilitate the further development of this curriculum, along with important resources related to each unit. These resources are valuable not only for their original content, but also for their references and footnotes, which, themselves, exponentially broaden the historical and theoretical terrain that may yield insights generative to the curriculum, its facilitators, and its participants. 
Table 1. Curriculum Questions and Resources

\begin{tabular}{|c|c|c|}
\hline Unit & Discussion Questions & Important Resources \\
\hline $\begin{array}{l}\text { Material Histories } \\
\text { and Dialectical } \\
\text { Materialism }\end{array}$ & $\begin{array}{l}\text { 1. When, where, why, and how did light } \\
\text { color become socially valued over dark } \\
\text { color? } \\
\text { 2. When, where, why, and how was } \\
\text { whiteness invented? } \\
\text { 3. How has social work affected and been } \\
\text { affected by whiteness? }\end{array}$ & $\begin{array}{l}\text { Allen, 1994-1997; } \\
\text { Brodkin, 1998; Hale, 1999; } \\
\text { López, 2006; Ignatiev, } \\
\text { 1995; Kendi, 2016; } \\
\text { Painter, 2010; Roediger, } \\
\text { 1991, 1994, 2005; } \\
\text { Thandeka, 2000 }\end{array}$ \\
\hline $\begin{array}{l}\text { Educ } \\
\text { Educ }\end{array}$ & $\begin{array}{l}\text { 1. How is the education system related to } \\
\text { ideologies of whiteness? } \\
\text { 2. How does whiteness affect students, as } \\
\text { learners and people, through education? } \\
\text { 3. How does whiteness operate through } \\
\text { language? }\end{array}$ & $\begin{array}{l}\text { Althusser, 1971; Bourdieu, } \\
\text { 1991; Bourdieu \& } \\
\text { Passeron, 1990; Bonilla- } \\
\text { Silva \& Zuberi, 2008; Hill, } \\
\text { 2008; Vološinov, } 1986\end{array}$ \\
\hline $\begin{array}{l}\text { Whiteness, Whites } \\
\text { and Beyond }\end{array}$ & $\begin{array}{l}\text { 1. How is whiteness different from whites? } \\
\text { 2. What is reconstructionism, how might } \\
\text { one enact it, and to what effect(s)? } \\
\text { 3. What is neo-abolitionism, how might } \\
\text { one enact it, and to what effect(s)? }\end{array}$ & $\begin{array}{l}\text { Ignatiev \& Garvey, 1996; } \\
\text { Gregory, 2020b; Kincheloe } \\
\text { et al., 1998; Leonardo, } \\
\text { 2009; Roediger, } 1994\end{array}$ \\
\hline
\end{tabular}

In the course of proposing this curriculum, it has been stated on the one hand that these lessons will get social work from where it is at (i.e., unaware that whiteness must be abolished or why) to where it needs to go (i.e., committed to the abolition of whiteness). On the other hand, the curriculum does not include a plan for what the abolition of whiteness looks like as praxis. This is intentional. The commitment to the abolition of whiteness is as far as the curriculum intends to go, for now. It is one thing for the curriculum to review and interpret available facts, and even to draw a conclusion that suggests a particular response. It would be another thing altogether for the curriculum to prescribe the manner of that response, at this stage. Neo-abolitionist social work praxis must grow from collective, participatory learning, and action. Ironically, if it did not, it would simply reproduce ways of knowing and being that are historically characteristic of whiteness. This would quickly become self-defeating. The present discussion - this transitional step between an article and a curriculum - is neither a collective nor participatory intellectual product, but a single exercise in extending an invitation to the larger social work community to join in a collaborative movement in theory and practice toward the abolition of whiteness. As such, this alone cannot envision the steps from theory to practice in a way that is inclusive or sustainable. The possibility and shape of neo-abolitionist social work praxis can only be realized by first attempting to implement a historically accountable critical whiteness curriculum for social work. Perhaps then, and only then, future iterations of the curriculum might include a plan for praxis. In a sense, the only way to finish is to begin. 
${ }^{i}$ As one piece of highly public and commonly known evidence that clearly illustrates the lack of urgency displayed by social work toward racial justice issues in comparison to matters of social justice unrelated to race, simply consider that the goal of ending racism was included as a "Grand Challenge for Social Work" only in 2020, seven years after the so-called challenges were introduced as a social work guiding framework in 2013 (Rao et al., 2021). ${ }^{\text {ii }}$ Hopefully the social worker that has already realized these truths will accept an apology, here, and understand that this necessary generalization is based upon and addressed to the overwhelming majority of social workers and prevailing social work institutions that have never considered the abolition of whiteness.

iii Jane Elliott's (2016) famous blue eyes/brown eyes experiment, originally conducted in 1968, represents perhaps the most classic case study on the observed effects of arbitrarily attaching social value to phenotypic traits, and illustrates the unnatural dissonance that social stratification must forcibly overcome in order to gain acceptance as a societal norm.

${ }^{\text {iv }}$ Paul Ricoeur (1986) says the following in his own attempt to put the matter of interpellation succinctly, which might provide helpful additional context where my own introduction of this concept is necessarily abbreviated: "Althusser's interesting analysis of what he calls 'interpellation' demonstrates more specifically the relationship between ideology and the subject ... We are constituted as subjects through a process of recognition. The use of the term 'interpellation' is an allusion to the theological concept of call, of being called by God. In its ability to interpellate subjects, ideology also constitutes them" (pp. 148-149).

" Baudelaire (1869/1970) originally wrote, "la plus belle des ruses du Diable est de vous persuader qu'il n'existe pas," or, roughly translated, "the most beautiful trick of the Devil is to persuade you that he does not exist" (p. 61).

${ }^{\text {vi }}$ Capital has to be understood here in the strict sense of surplus value.

vii Reconstructionism's ubiquity makes individual citations less meaningful as examples, but a few additional representative texts include Alcoff, 2015; Ellsworth, 1997; Giroux, 1997; and Feagin, 2013.

viii The reconstructionist literature has never fully separated whiteness from whites, and has consequently yet to respond to Roediger with a historical example of whiteness as anything other than oppressive and false. Reconstructionists frequently cite examples of whites who are not oppressive and false, testifying to the individual but not the social construction. If there is any part of whiteness that is, or ever has been, inherently positive and independent from an implicit, negative relation to BIPOC, reconstructionism has not identified it. 


\section{References}

Abrams, L. S., \& Dettlaff, A. J. (2020, June 18). An open letter to NASW and allied organizations on social work's relationship with law enforcement. Medium. https://medium.com/@alandettlaff/an-open-letter-to-nasw-and-allied-organizationson-social-works-relationship-with-law-enforcement-1a1926c71b28

Alcoff, L. M. (2015). The future of whiteness. Polity Press.

Allen, R. (2004). Whiteness and critical pedagogy. Educational Philosophy and Theory, 36(2), 121-136. https://doi.org/10.1111/j.1469-5812.2004.00056.x

Allen, T. W. (1994-1997). The invention of the white race (Vols. 1-2). Verso.

Althusser, L. (1971). Ideology and ideological state apparatuses: Notes toward an investigation. In L. Althusser (Ed.), Lenin and philosophy and other essays (pp. 127186). Monthly Review Press.

Anderson, C. (2016). White rage: The unspoken truth of our racial divide. Bloomsbury.

Applebaum, B. (2017). Comforting discomfort as complicity: White fragility and the pursuit of invulnerability. Hypatia, 32(4), 862-875. https://doi.org/10.1111/hypa.12352

Baldwin, J. (1985). The price of the ticket. St. Martin's Press.

Baudelaire, C. (1970). Paris spleen (L. Varèse, Trans.). New Directions. (Original work published 1869)

Bonilla-Silva, E. (2003). Racism without racists (5th ed.). Rowman \& Littlefield.

Bonilla-Silva, E., \& Zuberi, T. (2008). Toward a definition of white logic and white methods. In T. Zuberi \& E. Bonilla-Silva, E. (Eds.), White logic, white methods: Racism and methodology (pp. 3-27). Rowman \& Littlefield. https://doi.org/10.4324/9780203412107

Bourdieu, P. (1991). Language and symbolic power (J. B. Thompson, Ed.; G. Raymond $\&$ M. Adamson, Trans.). Harvard University Press.

Bourdieu, P., \& Passeron, J. (1990). Reproduction in education, society, and culture (2nd ed.). Sage Publications.

Brodkin, K. (1998). How Jews became white folks and what that says about race in America. Rutgers University Press.

Chandler, S. (2018). Social work, feminism, and prison abolition. Affilia, 33(1), 5-7. https://doi.org/10.1177/0886109917750961

de Montigny, G. A. (2013). The essentialism of whiteness: Abandoning empirical engagement. Journal of Social Work, 13(6), 633-651.

https://doi.org/10.1177/1468017312475279 
de Zurara, G. E. (1963). The chronicle of the discovery and conquest of Guinea (Vol. 2; C. R. Beazley \& E. Prestage, Trans.) [Ebook]. Burt Franklin. https://www.google.com/books/edition/The_Chronicle_of_the_Discovery_and_Conq u/1RpzAAAAMAAJ?hl=en\&gbpv=1\&printsec=frontcover

Dettlaff, A. J., Weber, K., Pendleton, M., Boyd, R., Bettencourt, B., \& Burton, L. (2020). It is not a broken system, it is a system that needs to be broken: The upEND movement to abolish the child welfare system. Journal of Public Child Welfare. Advance online publication. https://doi.org/10.1080/15548732.2020.1814542

DiAngelo, R. D. (2018). White fragility: Why it's so hard for white people to talk about racism. Beacon Press.

Dominelli, L. (1989). An uncaring profession? An examination of racism in social work. Journal of Ethnic and Migration Studies, 15(3), 391-403. https://doi.org/10.1080/1369183X.1989.9976127

Du Bois, W. E. B. (1935). Black reconstruction in America. The Free Press.

Du Bois, W. E. B. (2014). The souls of black folk. Millennium Publications. (Original work published 1903)

Dyer, R. (1997). White. Routledge.

Elliott, J. (2016). A collar in my pocket: The blue eyes brown eyes exercise. CreateSpace.

Ellsworth, E. (1997). Double binds of whiteness. In M. Fine, L. Weis, L. Powell, \& L. Wong (Eds.), Off white (pp. 259-269). Routledge.

Feagin, J. R. (2013). The white racial frame: Centuries of racial framing and counterframing (2nd ed.). Routledge. https://doi.org/10.4324/9780203076828

Feuerbach, L. (1893). The essence of Christianity [Ebook]. Pennsylvania State University. https://www.google.com/books/edition/The_Essence_of_Christianity/CsY4AQAAM AAJ $? \mathrm{hl}=\mathrm{en} \& \mathrm{gbpv}=1 \&$ printsec $=$ frontcover

Fox, C. (2012). Three worlds of relief: Race, immigration, and the American welfare state from the Progressive Era to the New Deal. Princeton University Press. https://doi.org/10.1515/9781400842582

Gilbert, N. (2016). Institutionalized discontent. Society, 53, 391-397. https://doi.org/10.1007/s12115-016-0033-5

Giroux, H. (1997). Rewriting the discourse of racial identity: Towards a pedagogy and politics of whiteness. Harvard Educational Review, 67(2), 285-320. https://doi.org/10.17763/haer.67.2.r4523gh4176677u8

Goldberg, C. A. (2008). Citizens and paupers: Relief, rights, and race, from the Freedmen's Bureau to workfare. University of Chicago Press.

Gould, S. J. (1996). The mismeasure of man. W. W. Norton. 
Gregory, J. R. (2020a). Social work as a product and project of whiteness, 1607-1900. Journal of Progressive Human Services, 32(1), 17-36. https://doi.org/10.1080/10428232.2020.1730143

Gregory, J. R. (2020b). The imperative and promise of neo-abolitionism in social work. Journal of Social Work. Advance online publication. https://doi.org/10.1177/1468017320952049

Gustafson, K. (2009). The criminalization of poverty. Journal of Criminal Law and Criminology, 99(3), 643-716.

https://scholarlycommons.law.northwestern.edu/cgi/viewcontent.cgi?article=7330\&c ontext $=$ jclc

Hale, G. E. (1999). Making whiteness: The culture of segregation in the south, 18901940. Vintage.

Harris, C. I. (1993). Whiteness as property. Harvard Law Review, 106(8), 1707-1791. https://www.jstor.org/stable/1341787

Hartman, A. (2004). The rise and fall of whiteness studies. Race \& Class, 46(2), 22-38. https://doi.org/10.1177/0306396804047723

Hartmann, D., Gerteis, J., \& Croll, P. R. (2009). An empirical assessment of whiteness theory: Hidden from how many? Social Problems, 56(3), 403-424. https://doi.org/10.1525/sp.2009.56.3.403

Hening, W. W. (Ed.). (1823). The statutes at large; Being a collection of all the laws of Virginia from the first session of the legislature, in the year 1619 [Ebook]. R. \& W. \& G. Bartow. https://catalog.hathitrust.org/Record/009714930

Hill, J. (2008). The everyday language of white racism. Wiley-Blackwell.

Ignatiev, N. (1995). How the Irish became white. Routledge.

Ignatiev, N. (1997, April 11-13). The point is not to interpret whiteness but to abolish it [Conference session]. The Making and Unmaking of Whiteness Conference, Berkeley, CA, United States. https://blog.pmpress.org/2019/09/16/the-point-is-not-tointerpret-whiteness-but-to-abolish-it/

Ignatiev, N., \& Garvey, J. (Eds.). (1996). Race traitor. Routledge.

Jeyasingham, D. (2012). White noise: A critical evaluation of social work education's engagement with whiteness studies. British Journal of Social Work, 42, 669-686. https://doi.org/10.1093/bjsw/bcr110

Katz, M. B. (1986). In the shadow of the poorhouse. Basic Books.

Kendi, I. X. (2016). Stamped from the beginning: The definitive history of racist ideas in America. Bold Type Books.

Kincheloe, J., \& Steinberg, S. (1998). Addressing the crisis of whiteness: Reconfiguring white identity in a pedagogy of whiteness. In J. Kincheloe, S. Steinberg, N. Rodriguez, \& R. Chennault (Eds.), White reign (pp. 3-29). St. Martin's Griffin. 
Kincheloe, J., Steinberg, S., Rodriguez, N., \& Chennault, R. (Eds.). (1998). White reign. St. Martin's Griffin.

Lee, E., \& Bhuyan, R. (2013). Negotiating within whiteness in cross-cultural clinical encounters. Social Service Review, 87(1), 98-130. https://doi.org/10.1086/669919

Leiby, J. (1978). A history of social welfare and social work in the United States. Columbia University Press.

Leonardo, Z. (2009). Race, whiteness, and education. Routledge.

Leonardo, Z., \& Manning, L. (2017). White historical activity theory: toward a critical understanding of white zones of proximal development. Race Ethnicity and Education, 20(1), 15-29. https://doi.org/10.1080/13613324.2015.1100988

Lipsitz, G. (1998). The possessive investment in whiteness: How white people profit from identity politics. Temple University Press.

López, I. H. (2006). White by law: The legal construction of race (2nd ed.). New York University Press.

Marx, K., \& Engels, F. (1970). The German ideology. International Publishers. (Original work published 1932)

Matias, C. E. (2016). Feeling white: Whiteness, emotionality, and education. Sense Publishers.

McIntosh, P. (1989, July/August). White privilege: Unpacking the invisible knapsack. Peace and Freedom, 10-12. https://nationalseedproject.org/Key-SEED-Texts/whiteprivilege-unpacking-the-invisible-knapsack

Morgan, E. S. (1975). American slavery, American freedom: The ordeal of colonial Virginia. W. W. Norton.

Morrison, T. (1970). The bluest eye. Alfred A. Knopf.

National Center for Education Statistics. (2018). Number and percentage of homeschooled students ages 5 through 17 with a grade equivalent of kindergarten through 12th grade, by selected child, parent, and household characteristics: Selected years, 1999 through 2016. Digest of Education Statistics. https://nces.ed.gov/programs/digest/d18/tables/dt18 206.10.asp

Neill, E. D. (1875). Notes on American history. The New England Historical and Genealogical Register, 28, 295.

Network to Advance Abolitionist Social Work. (2021). What is abolitionist social work? https://www.naasw.com/about

Niemonen, J. (2010). Public sociology or partisan sociology? The curious case of whiteness studies. The American Sociologist, 41(1), 48-81. https://doi.org/10.1007/s12108-010-9086-x 
Nopper, T. K. (2010, January 19). The white anti-racist is an oxymoron: An open letter to "white anti-racists." http://whyaminotsurprised.blogspot.com/2010/01/tamara-knopper-to-white-anti-racists.html

Nylund, D. (2006). Critical multiculturalism, whiteness, and social work: Towards a more radical view of cultural competence. Journal of Progressive Human Services, 17(2), 27-42. https://doi.org/10.1300/J059v17n02_03

Obasogie, O. K., Harris-Wai, J. N., Darling, K., Keagy, C., \& Levesque, M. (2015). Race in the life sciences: An empirical assessment, 1950-2000. Fordham Law Review, 83, 3089-3114. https://ir.lawnet.fordham.edu/flr/vol83/iss6/9/

Painter, N. I. (2010). The history of white people. W. W. Norton.

Pimpare, S. (2007). Toward a new welfare history. The Journal of Policy History, 19(2), 234-252. https://doi.org/10.1353/jph.2007.0012

Piven, F. F., \& Cloward, R. A. (1993). Regulating the poor: The functions of public welfare (2nd ed.). Random House.

Rao, S., Woo, B., Maglalang, D. D., Bartholomew, M., Cano, M., Harris, A., \& Tucker, T. B. (2021). Race and ethnicity in the Social Work Grand Challenges. Social Work, 66(1), 9-17. https://doi.org/10.1093/sw/swaa053

Richie, B. E., \& Martensen, K. M. (2020). Resisting carcerality, embracing abolition: Implications for feminist social work practice. Affilia, 35(1), 12-16. https://doi.org/10.1177/0886109919897576

Ricoeur, P. (Author), \& Taylor, G. (Ed.). (1986). Lectures on ideology and utopia. G. Taylor (Ed.). Columbia University Press.

Roediger, D. R. (1991). The wages of whiteness: Race and the making of the American working class. Verso.

Roediger, D. R. (1994). Towards the abolition of whiteness. Verso.

Roediger, D. R. (2005). Working toward whiteness: How America's immigrants became white. Basic Books.

Russell, P. E. (2000). Prince Henry "the navigator”: A life. Yale University Press.

Smalling, S. E. (2015). Silence is not an option. Reflections, 21(3), 50-52. https://reflectionsnarrativesofprofessionalhelping.org/index.php/Reflections/article/vi ew/1563

Sullivan, S. (2014). Good white people: The problem with middle-class white antiracism. State University of New York Press.

Thandeka. (2000). Learning to be white: Money, race, and God in America. Continuum.

Twine, F. W., \& Gallagher, C. (2008). The future of whiteness: A map of the "third wave." Ethnic and Racial Studies, 31(1), 4-24. https://doi.org/10.1080/01419870701538836 
UNESCO Institute for Statistics. (2020). Out-of-school rate by school age and sex (administrative data). UIS Statistics. http://data.uis.unesco.org/Index.aspx

Vološinov, V. N. (1986). Marxism and the philosophy of language (L. Matejka \& I. R. Titunik, Trans.). Harvard University Press.

Vought, R. (2020). M-20-34: Memorandum for the heads of executive departments and agencies: Training in the federal government. Executive Office of the President: Office of Management and Budget. https://www.whitehouse.gov/wpcontent/uploads/2020/09/M-20-34.pdf

Author note: Address correspondence to Joshua R. Gregory, School of Social Welfare, University of California, Haviland Hall, Berkeley, CA 94709. Email:

jrgregory@berkeley.edu 